Journal of Education and Vocational Research

Vol. 4, No. 5, pp. 146-158, May 2013 (ISSN 2221-2590)

\title{
Perceptions of Auditors in Malaysia on the Important Items of Internet Financial Reporting
}

\author{
*Mohd Noor Azli Ali Khan, Nurul Ain Omar \\ Universiti Teknologi Malaysia, Johor Bahru, Johor, Malaysia \\ *m-nazli@utm.my
}

\begin{abstract}
This study investigates the perceptions of auditors regarding the important items in the disclosure of content and presentation dimension that can be used to describe the level of internet financial reporting (IFR). Questionnaires were distributed to 100 auditors. A total of 40 questionnaires were completed and returned, giving a response rate of 40 percent. From the survey, it was found that the five most important items in the content dimension are income statement of current year, income statement of past years, cash flow statement of current year, notes to financial statements of current year and balance sheet of current year. Meanwhile, in the presentation dimension, five most items important to disclosure are loading time of the website below 10 seconds, annual report in PDF format, hyperlinks inside the annual report, ability to download reports and hyperlinks to financial analysts. Finally, the limitation of this study and future research will also be discussed.
\end{abstract}

Keywords: auditors, content, index, Internet Financial Reporting, Malaysia, and presentation

\section{Introduction}

Nowadays, most companies use the internet as a tool to deliver information regarding their company's financial reporting by using the World Wide Web (WWW) as a medium to display the company's financial data, annual reports, databases on press release and also other related information for financial disclosure about the company activity (Delleret al., 1999). The internet has become a powerful tool for corporate communication in recent times (Oyelere \& Kuruppu, 2012). The internet is also another way used by companies to share information, apart from using the existing printed based practices (Lymer \& Debrecency, 2003). Furthermore, the internet is a medium to communicate in order to exchange information globally, which brings opportunities in fast delivery and is economical in obtaining information (Al-Htaybat, 2011). When a company is willing to exchange business information and build business globally on the internet, it becomes part of the company network by adopting internet financial reporting (hereinafter referred to as IFR) (Lymer \& Debreceny, 2003; Hansen, 2001). The recent development in the area of information and communication technology (ICT) has profoundly altered the way corporate information disseminated among stakeholders (Samahaet al., 2012). Adopting the internet has become a phenomenon throughout the world today and is continuously growing during the recent years (Moradi et al., 2011; Fisher et al., 2004). Companies use websites to deliver information to stakeholders of financial reporting (Velmurugan, 2009; Fisher et al., 2004). Many countries have also developed securities markets, such as Bursa Malaysia, which uses information technology (IT) for corporate reporting and is very well established (Lymer \& Debreceny, 2003). Moreover, the usage of the internet, known as IT, by firms has become increasingly sophisticated and more complex (Virginia \& Michael, 2003). However, less researchers study the importance of IFR practices and the effectiveness in disclosing financial reporting (Ismail \& Sobhy, 2009; Mirshekary \& Saudagaran, 2005).

The implementation of disclosing financial reporting using internet as a medium to deliver information creates unique opportunities, challenges and implication for auditors (Fisher et al., 2004). The technology gives the impact of implementing IFR and is derived from other factors such as globalisation and notion accountability, which brings changes in audit practice on financial reporting (Sumiani et al., 2007; Fisher et al., 2004). Yet, no specific body has issued a formal standard to highlight or investigate the issues of auditing in IFR practices (Ohman \& Wallerstedt, 2012; Fisher et al., 2004; Lymer \& Debrecency, 2003). The increasing number of financial reporting disclosures brings audit issues and subsequently, the disclosure of financial statement with some restrictions on information will increase the potential of misleading interpretation 
among users of financial reporting such as auditors (Lymer \& Debrecency, 2003). There are many researchers who have studied the issue of IFR in many developing countries, bringing benefits towards users of corporate financial statement (Ismail \& Sobhy, 2009; Mirshekary \& Saudagaran, 2005). Nevertheless, there is little empirical evidence on the disclosure of financial reporting on the factors influencing the practice in Asian listed companies (Ho \& Kar, 2001). Therefore, these studies intend to investigate disclosure issues of financial reporting towards users. Furthermore, there are less participation in previous studies researching about the impact of IFR on audit professionals and audit task and procedures on audit issues (Ismail \& Sobhy, 2009; Xiao et al., 2002). Hence, by implementing IFR audit problems occur and the auditors' perception needs to be analysed on a more comprehensive framework (Ismail \& Sobhy, 2009). Thus, this study intends to research about IFR from auditors regarding their perception where they are part of the users. As auditors, they are exposed to IT systems to determine the terms in records, processes and report transactions or other related financial data and can also facilitate their understanding regarding financial reporting disclosure issues (Virginia \& Michael, 2003; Ho \& Kar, 2001). Auditors serve as a part towards contributing to the company's performance to measure whether the company is approved of. Hence, auditors nowadays face many IT environments, which involve data received by electronic rather than paper based media (Virginia \& Michael, 2003). Moreover, auditors should increase their awareness on the consequences of IFR during audit fieldwork (Ismail \& Sobhy, 2009).

In addition, in developing internet environment in financial reporting, it needs reviews from securities regulators and audit standards. In addition, they give guidelines to the auditors on the implications of IFR from being manipulated when receiving data (Lymer \& Debreceny, 2003). Thus, researchers noticed that there are an increasing number of unsatisfied users, especially auditors, towards the organisation's behaviour for not really updating their financial statement in the current year, thus making it difficult for auditing purpose (Joshi \& Al-Modhahki, 2003). Useful financial reporting should be presented in understandable, credible and timeliness manner, as they are important characteristics influenced by both preparers and users of financial reporting (Naser et al., 2003). It is also hoped to make this research a basis for other studies on IFR disclosure, which highlights auditor as the main indicator to research in detail. Besides, these researches are essential for every organisation to improve their disclosure related to financial reporting and to be more transparent in disclosing their financial reporting (Ho \& Kar, 2001; Rahman, 1998). Thus, to make it more transparent, quarterly corporate financial statement should be introduced (Ku Ismail \& Chandler, 2005). Nevertheless, it is not sufficient to maintain transparency for the annual report presented (Ho \& Kar, 2001). Information in financial reporting was rated as primary sources of information in various users of corporate reporting (Alattar \& Al-Khater, 2007; Mirshekary \& Saudagaran, 2005; Naser et al., 2003). Therefore, the objectives of this study are to investigate the perception of auditors towards the important items of IFR disclosure in terms of content and presentation dimension presented. The impact of this study will support the empirical evidence related to auditors' perception on IFR that is going to be highlighted. This article is presented as the following: IFR is analysed from previous studies and next is the methodology used then we will come up with the analysis and findings of the study. Finally, the last part will present the conclusion of the study and several recommendations for future research.

\section{Previous Studies}

The characteristics of financial reporting disclosure are that it must be reliable, material, relevant and easy to understand (Ho \& Kar, 2001). Advanced technology leads IFR to become more interesting by further investigating two main dimensions, which are content and presentation dimensions to measure the important items of IFR disclosure that should be present in IFR (Ali Khan \& Ismail, 2012). There are many benefits of implementing IFR dimension such as to academicians and industrialists, and have contributed in developing IFR to obtain information in an effective manner (Ali Khan \& Ismail, 2011). Evidently, there are many dimensions that were introduced, such as content and timeliness, timeline basis, technology and customer support, and lastly content and usability (Ali Khan \& Ismail, 2011). Hence, to measure the important items of financial reporting disclosure level of IFR, two dimensions were usually used; namely content and presentation (Ali Khan \& Ismail, 2011). Thus, most researchers like to focus only on annual report of the IFR itself (Abdul Rahman, 2001). There are several reasons for the implementation of content and presentation dimensions stated from previous studies. Firstly, it is frequently used and it is popular to indicate the important items of financial reporting disclosure from previous studies (Debrecency et al., 2002; 
Ali Khan, 2010). Secondly, from previous studies, there are indications that the disclosure of important items in financial reporting would enhance corporate transparency (Ali Khan, 2010; Lymer \& Debreceny, 2003). In addition, other important criteria of financial reporting consist of timeliness disclosure, reliability and auditor environment (Ku Ismail \& Chandler, 2005). Timeliness is about the duration of presenting the financial reporting for disclosure to promote transparency (Lymer \& Debreceny, 2003). In other words, it is promoted to minimise the problem of inside information, encourage reliable information and also to make it accessible to users. In Malaysian practices, financial reports are submitted to Bursa Malaysia within two month before the end of the year (Ku Ismail \& Chandler, 2005).

Advantages and Disadvantage of IFR: Using IFR will save cost, has wider reach and is easy to access (Celik et al., 2006; Debreceny et al., 2002). Although using the internet encourages cost saving, it still incurs some additional costs if companies are willing to use traditional methods such as paper-based together with internet-based ones (Fisher et al., 2004; Xiao et al., 2002). This can improve the accessibility of information that results in more equitable information dissemination (Fisher et al., 2004; Oyelere et al., 2003; Fisher et al., 2000). Others advantages of IFR from a previous study are that they are attractive for readers, easy to understand and save time in analysing data (Mohd Isa, 2006). Basically, new technologies introduced like IFR need someone who has knowledge and experience to handle it. Thus brings the limitation to such according to the ways of implementation and compliance and the quality of the overall disclosure may be less effective (Stoel et al., 2012; Ho \& Kar, 2001). The IFR is exposed to unauthorised access risk when it is not properly managed, and then also leads to others to insert errors into the data files, which can cause security problem (Hansen, 2001). There are many critical changes since adopting IFR of corporate performance (Lymer \& Debreceny, 2003). Some of them are that it will incur some problems such as security problem and authentication, attestation and legal impediments, and cost and expertise (Ali Khan \& Ismail, 2009; Joshi \& AlModhahki, 2003). Several factors contribute to lower effectiveness in using financial reporting, for instance delay in published financial reporting in the current year, lack of trust and lack of adequate information in the credibility of the financial reporting and excessive risk exposures such as being easy to manipulate (Mirshekary \& Saudagaran, 2005; Ho \& Kar, 2001).

Auditors Perspective: In the auditors' perspective, reliability is an important element for auditing purpose to ensure the information received are of quality, free from error of fraud, and also represent accuracy (Ku Ismail \& Chandler, 2005). In other words, reliability is an important issue to highlight which is not specifically subjected to the auditor himself but it concerns the frequently exposed disclosed information that have higher risk of accounting error. In addition, the main issues in the auditors environment are the role and responsibility of information on websites, the high potential of unaudited financial reporting, omission of audit report, inappropriate audit issues, and also timing, nature of the content form of the audit report on a website (Griffiths, 2012; Ismail \& Sobhy, 2009; Fisher et al., 2004; Lymer \& Debreceny, 2003; Xiao et al., 2002). Changes in the roles of the IFR development required auditors to report activities from paper-based to online reporting (Virginia \& Michael, 2003). Report incorporated in printed financial reporting is easier for the auditors to recognise the document (Debreceny \& Gray, 1999). Subsequently, lack of information in the financial reporting presented on the internet is a problem to auditors (Debreceny \& Gray, 1999). In addition, financial reporting in internet has a high risk on not being updated, which will reduce the reliability of information (Ismail \& Sobhy, 2009; Xiao et al., 2002). Hence, there is a need for regulation and control in the growing number of internet usage for financial reporting to avoid securities problem (Xiao et al., 2002). Usually, financial reporting shows a part of the corporate website, has potential numbers of misleading information alongside the financial data. Thus, the auditor is the one responsible if the data are not relevant for auditing and has become problematic (Lymer \& Debreceny, 2003). As Debreceny and Gray (1999) noted, there are several issues highlighted to audit in IFR such as the document presented on a website that can be changed and are difficult for auditors to identify the documents accordingly. Another issue is the security of the auditor's report in the internet environment and the nature of the evidence of document review, which brings additional risk associated with online system and increasing litigation risk for auditors (Fisher et al., 2004). Audit reports are always exposed to changes in information by others such as hackers, which increase the risk in IFR (Ismail \& Sobhy, 2009). Others than that, organisations that lack in organising and managing a web and the ability to have all web resources will bring problem to an auditor. As there is limited number of researchers, there is no national professional body issuing a formal standard to address specific auditing issues as stated (Fisher et al., 2004). 
There are several issues highlighted. One of them is that the currently unregulated financial reporting disclosure on the internet arises because of the global nature and the law stated on internet environment not being appropriate (Fisher et al., 2004; Lymer \& Debrecency, 2003). Sometimes, there are some errors when publishing information on the internet during the conversion or transposition process. In addition, information presented can be modified by unauthorised users internal or external to the presenting financial reporting (Velmurugan 2009; Fisher et al., 2004; Hansen, 2001). In a worse situation, information can be manipulated or very fluid in nature such that it can be easy to modify or delete remotely at any point in time without leaving any of these actions thus the information are not accurate anymore. Financial reporting in Malaysia is low that disclose financial reporting in general information to users (Sumiani et al., 2007). Moreover, there is no specific formatting structure or rules and requirement on how auditing work should be performed in IFR (Ohman \& Wallerstedt, 2012). In addition, the reliance of auditors on IT makes it important to set up new regulations regarding the auditing practice in IFR (Stoel et al., 2012). This can be done by setting up the standards on auditing involvement and to minimise audit issues by producing a new form of reporting by frequency and data orientation rather than information orientation (Griffiths, 2012; Ismail \&Sobhy, 2009). Consequently, applying the set of regulations and law will make improvement in the auditing practice (Ohman \& Wallerstedt, 2012; Stoel et al., 2012; Velmurugan, 2009). From the audit issues, some improvement should be highlighted as the increase in the quality of the audit IT process will improve the IFR results (Stoel et al., 2012).

\section{Methodology}

Research Design: Proper structuring of the questionnaire plays an important role in determining the accuracy of the data to be collected. Thus, questionnaires should be clear for the respondents and oriented towards the objective of the research (Davies, 2007). The questionnaire for this research is extracted from a previous study (Stoel et al., 2012; Ali Khan \& Ismail, 2010; Ismail et al., 2009; Fisher et al., 2004; Lymer \& Debreceny, 2003). The researcher sent out questionnaires to solicit auditors' opinion and feedback on IFR issues in relation to auditing issues. The questionnaire required respondents to grade the importance of each item on a scale of 1 to 5 for content, presentation dimension and audit issues, where 5 meant that the item was extremely important, 4 as important, 3 as rarely important, 2 as not important, and 1 as not important at all.

Sample: Sample size is used to identify the population to be selected for the purpose of the research (Devies, 2007; Creswell, 2005). In other words, the sample size plays an important part to identify the accuracy of the data involved. Thus, the level of accuracy of the research can be measured in a suitable appropriate size of the sample (Bartlett et al, 2001). There are 40 audit companies in Johor Bahru, Johor. Hence, to decide the size of the population, the researcher used a range of 36 companies (Krejcie \& Morgan, 1970).

Data Collection: A hundred questionnaires were distributed to the auditors, in which the process of collecting data took approximately two weeks to complete, the distribution of questionnaires was from 8 October 2012 to 15 October 2012 plus another week for the respondents to complete the questionnaire. The questionnaires were distributed randomly to the respondents by providing five sets of questionnaire to each company. In the end, only 40 sets were collected. It seemed that some respondents lacked in participation due to having no time to entertain and giving less corporation. These were the major factors that contributed to less questionnaires collected.

Response Rate: Only 40 completed questionnaires were collected which represents a response rate of 40 percent. The percentage involved are in between the percentage from the previous studies with a response rate of 43 percent (Mohd Isa, 2006), 49 percent (Mirshekary \& Saudagaran, 2005), followed by other researcher response rates, 13.29 percent (Mohd Isa, 2006), 17.2 percent (Ho\& Wong, 2001), 14.4 percent (Ku Ismail \& Chandler, 2005), and 15.11 percent (Ali Khan, 2010). Hence, the response rate in this research is acceptable and reliable when compared to previous studies. In addition, many efforts had been taken to improve the response rate, including extending the period of answering the questionnaires for the respondents and also shortening the length of the questionnaire. 
Data Analysis: After the questionnaires have been collected by the researcher, all the data were entered into computer software named Statistical Package for Social Science (SPSS) to process the raw data. The analysis of the data collected uses three steps to measure the accuracy and validity, namely Cronbach's Alpha Reliability Test, Descriptive and Frequency Analysis. Thus, the data analysis identified the result structure and interpretation about the data collected (Marshall \& Rossman, 1999). In other words, data analysis is an importance tool to measure the accuracy and validity of the data to obtain the result. To measure the accuracy of the research, descriptive statistics was used in order to explore the data collected. Descriptive figure is used to examine the validity of the sample data (Heller \& Greene, 2012). Mean is used to make some general information about the date collected. In this study, descriptive analysis is used to determine the important items of disclosure in the content and presentation dimensions, and audit issues. Meanwhile, standard deviation and variance give more information about the distribution of each variable. Thus, by adopting Descriptive Analysis, the major types of descriptive statistics such as frequencies, mean, variance, standard deviation, measure of control tendency, range, maximum and minimum score can be identified. Furthermore, to make the classification of mean easy to identify, the group of classification of mean from previous studies is used: greatly important for mean exceeding 4.00, moderately important for mean in the range of 3.00 to 4.00, and slightly important for mean less than 2.00 (Mirshekary \& Saudagaran, 2005; Ali Khan, 2010).

\section{Findings and Discussions}

Table 1 below displays the demographic background details obtained from 40 respondents, which are auditor in Johor Bahru, Johor who are involved in this study. Out of 40 auditors, 10 were males 25 percent and 30 were females' respondents 75percent. In terms of age, 26 auditors are aged below 30 years old 65 percent and 14 auditors between 31 to 40 years old 35 percent. Only five auditors are diploma holders 12.5 percent while 32 respondents are degree holders 80 percent and only three auditors are master holder 7.5 percent. For the scope of their academic field, most auditors are from an accounting background 85 percent and a small amount is from accounting and finance which is only six auditors 15 percent. Meanwhile, most of the respondents have an experience in the auditing field for less than five years which are 27 people 67.5 percent, while in between five to ten years there are 10 respondents 25.2 percent, only one auditor has between 11 to 15 years 2.5 percent and only two auditors has working experience around 16 to 20 years 5.0 percent.

Table 1: Profile of Auditors ( $n=40)$

\begin{tabular}{llll}
\hline Demographic & Item & Frequency & Percentage (\%) \\
\hline Gender & Male & 10 & 25 \\
\multirow{3}{*}{ Age } & Female & 30 & 75 \\
\multirow{2}{*}{ Academic qualification } & <30 years & 26 & 65 \\
& $31-40$ years & 14 & 35 \\
\multirow{3}{*}{ Majoring } & Diploma & 5 & 12.5 \\
\multirow{3}{*}{ Number of years working in } & Degree / Professional & 32 & 80 \\
organization & Master & 3 & 7.5 \\
& Accounting & 34 & 85.0 \\
& Accounting \& Finance & 6 & 15.0 \\
& $<5$ years & 27 & 67.5 \\
& $5-10$ years & 10 & 25.2 \\
& $11-15$ years & 1 & 2.5 \\
\hline
\end{tabular}

Table 2 shows the amount of alpha of each dimension present. From the result, each dimension to obtain the auditors perception on IFR must score a reliability coefficient (alpha) of greater than 0.7 to be accepted as reliable in this study (Radhakrishna, 2007; Field, 2005). Overall, the alpha value in Table 2 of each dimension is consistent. 
Table 2: The Level of Reliability $(n=40)$

\begin{tabular}{lll}
\hline Dimension & No of Item & Cronbach's Alpha \\
\hline Content & 97 & 0.973 \\
Presentation & 58 & 0.971 \\
Audit issues & 7 & 0.890 \\
\hline
\end{tabular}

Next, to determine the importance of content dimension in Table 3, respondents were required to provide feedback on 97 items. Thus, Table 3 shows the items important in content dimension measured by the value of mean. From the result obtained, 30 items exceeded the mean value of 4.00. Meanwhile, findings showed that 90 items listed under content dimension were categorised as important item as the mean exceeded 3.50. The balance of seven items was categorised as unimportant with a mean lesser than 3.50. This showed the importance of IFR from previous studies in content dimension (Ali Khan et al., 2012; Ali Khan, 2010; Ali Khan \& Ismail, 2010; Ali Khan \& Ismail, 2008; Ho \& Kar, 2001)was used to measure the content dimension of IFR index. Thus, from the 97 disclosure index items that were presented, only 30 items were categorised as very important the mean exceeded 4.00. In addition, the ranking among the top five disclosure items to show the level of IFR for content dimension are (1) income statement of current year, (2) income statement of past years, (3) cash flow statement of current year, (4) notes to financial statement of current year, and (5) balance sheet of current year. The result are quite consistent with the previous study which stated income statement, balance sheet, cash flow statement, note to accounts and director report as the five most important items in financial reporting (Ho \& Kar, 2001). Other than that, another previous research indicated the five important items in financial reporting as profit and loss account, auditor's report, balance sheet, notes to accounts and statement of cash flow (Mirshekary \& Saudagaran, 2005). Moreover, a different researcher classified five important items in user's rating of the degree of credibility in financial reporting as financial statement, financial position, notes to financial statements, directors' report and auditor's report (Naser et al., 2003). On the other hand, five important items in the financial reporting section are: balance sheet, notes to the account, income statement, auditor's report and cash flow statement (Alattar \& Al-Khater, 2007). Meanwhile, the lowest five items to determine content dimension are: (1) past year resolutions of the Supervisory Board, (2) phone number to investor relations, (3) postal address to investor relations, (4) monthly or weekly sale or operating data, and (5) e-mail to investor relations. In summary, basically in annual report, the important part users usually analyse is profit and loss account, which classifies as income statement, followed by balance sheet and the statement of cash flows (Abdul Rahman, 2001). All the result in Table 3 is consistent with previous study.

Table 3: Auditors' Perception on the Disclosure Item for Content Dimension

\begin{tabular}{|c|c|c|c|c|}
\hline \multicolumn{2}{|c|}{ Disclosure Item } & Mean & Std. Dev. & Rank \\
\hline \multicolumn{5}{|c|}{ Great Importance } \\
\hline 1 & Income statement of current year & 4.62 & .586 & 1 \\
\hline 2 & Income statement of past years & 4.60 & .545 & 2 \\
\hline 3 & Cash flow statement of current year & 4.60 & .545 & 3 \\
\hline 4 & Notes to financial statements of current year & 4.57 & .501 & 4 \\
\hline 5 & Balance sheet of current year & 4.57 & .594 & 5 \\
\hline 6 & Auditor report of current year & 4.55 & .597 & 6 \\
\hline 7 & Balance sheet of past years & 4.52 & .599 & 7 \\
\hline 8 & Annual report of current year (full text) & 4.50 & .679 & 8 \\
\hline 9 & Cash flow statement of past year & 4.45 & .504 & 9 \\
\hline 10 & Statement of changes in shareholders' equity & 4.45 & .597 & 10 \\
\hline 11 & Auditor report of past years & 4.42 & .594 & 11 \\
\hline 12 & Notes to financial statements of past years & 4.35 & .533 & 12 \\
\hline 13 & Auditor signature of current year & 4.30 & .687 & 13 \\
\hline 14 & Financial Reporting Standard (FRS) basis in the current year & 4.25 & .707 & 14 \\
\hline 15 & English version of annual report & 4.20 & .723 & 15 \\
\hline & Supplement or amendment to current year annual report & 4.18 & .594 & 16 \\
\hline
\end{tabular}


17 Accounting policy

18 Annual report of past years (full text)

$\begin{array}{lll}4.17 & .844 & 17\end{array}$

19 Changes in stockholders' equity in the current year

$\begin{array}{lll}4.15 & .662 & 18\end{array}$

20 Summary of annual report of current year

$\begin{array}{lll}4.15 & .736 & 19\end{array}$

21 Company address

$\begin{array}{lll}4.15 & .736 & 20\end{array}$

22 Auditor signature in past years report

$\begin{array}{lll}4.12 & .648 & 21\end{array}$

23 Financial ratios

$\begin{array}{lll}4.12 & .791 & 22\end{array}$

24 Analyses of main business risks

25 Management report/analysis in current year

$4.08 \quad .656$

$\begin{array}{lll}4.07 & .694 & 24\end{array}$

26 Dividend information

$\begin{array}{lll}4.07 & .730 & 25\end{array}$

27 Current share prices

$4.05 \quad .714$

$4.02 \quad .577-27$

28 Web page in English

$4.02 \quad .891$

29 Share price performance in relation to stock market index

$4.00 \quad .784$

30 CEO signature in the report

$4.00 \quad .847$

30

Moderate Important

$\begin{array}{lllll}31 & \text { Users quickly find the financial information } & 3.98 & .660 & 31\end{array}$

$\begin{array}{lllll}32 & \text { Sales of key products } & 3.98 & .800 & 32\end{array}$

33 Summary of financial data over a period of at least five years $\quad \begin{array}{llll}3.95 & .639 & 33\end{array}$

34 Segmental reporting by line of business in current year

$3.95 \quad .639 \quad 34$

35 Members of the Board of Directors

$3.95 \quad .714 \quad 35$

36 Indicator for finding current information directly

$3.95 \quad .714 \quad 36$

37 Half-year report of current year

$3.92 \quad .656 \quad 37$

38 Summary of key ratios over a period of at least five years

$3.92 \quad .764$

39 Shareholder information

$\begin{array}{lll}3.90 & .672 \quad 39\end{array}$

40 Other than English web page (such as Malay)

$\begin{array}{lll}3.90 & .744 & 40\end{array}$

41 Disclaimer

42 Charters for the audit committee

$\begin{array}{lll}3.88 & .686 & 41\end{array}$

$\begin{array}{lll}3.88 & .883 \quad 42\end{array}$

43 Corporate information

$3.85 \quad .580$

44 Number of share traded

3.85

.700

44

45 Classes of shares

$3.82 \quad .594$

45

$\begin{array}{lll}3.82 & .747 & 46\end{array}$

46 Directors shareholding information

$3.78 \quad .577$

47

48 Current year information can be distinguished from last year's information

3.78

.620

48

49 Projected information

3.78

.660

49

50 Share quote

$3.78 \quad .660$

50

51 Information on the date of latest websites update

$3.78 \quad .733$

51

52 Company's charter in the current year

$3.78 \quad .768$

52

53 Annual report of current year (excerpt)

$3.78 \quad .800 \quad 53$

54 Quarterly report of current year

$3.78 \quad .800$

54

55 Information on intellectual capital

$3.75 \quad .630$

55

56 Historical share prices

$3.75 \quad .630$

56

57 Frequently Asked Question (FAQ)

$3.75 \quad .776$

57

58 Specific update time for the stock/share price data

$3.75 \quad .776$

58

59 Current press releases or news

$\begin{array}{ll}3.75 & .809\end{array}$

59

60 Link to Bursa Malaysia websites

3.75

.809

60 


\begin{tabular}{|c|c|c|c|c|}
\hline 61 & Annual report of past years (excerpt) & 3.75 & .840 & 61 \\
\hline 62 & Segmental reporting by region in current year & 3.72 & .679 & 62 \\
\hline 63 & Chairman's report & 3.72 & .877 & 63 \\
\hline 64 & Monthly share prices & 3.70 & .564 & 64 \\
\hline 65 & $\begin{array}{l}\text { Indication of audited and unaudited information (half yearly and } \\
\text { quarterly) }\end{array}$ & 3.70 & .723 & 65 \\
\hline 66 & Half-year report of past years & 3.70 & .648 & 66 \\
\hline 67 & Quarterly report of past years & 3.70 & .648 & 67 \\
\hline 68 & Annual general meetings information & 3.70 & .853 & 68 \\
\hline 69 & Recent monthly financial data & 3.68 & .797 & 69 \\
\hline 70 & Corporate social responsibility report & 3.68 & .797 & 70 \\
\hline 71 & Corporate governance principles/guidelines & 3.68 & .797 & 71 \\
\hline 72 & Segmental reporting by region in past years & 3.65 & .662 & 72 \\
\hline 73 & Information regarding a dividend reinvestment plan & 3.63 & .667 & 73 \\
\hline 74 & Current year resolutions of the Board of Directors & 3.63 & .807 & 74 \\
\hline 75 & Calendar of events of interests to investors & 3.63 & .807 & 75 \\
\hline 76 & Calendar of future financial activities & 3.63 & .952 & 76 \\
\hline 77 & Share price graphs & 3.62 & .740 & 77 \\
\hline 78 & Information on corporate strategy & 3.60 & .778 & 78 \\
\hline 79 & Current year resolutions of the Supervisory Board & 3.60 & .810 & 79 \\
\hline 80 & $\begin{array}{l}\text { Code of conduct and ethics for directors, officers and employee } \\
\text { (employer) }\end{array}$ & 3.58 & .813 & 80 \\
\hline 81 & Current year resolutions of shareholders' meeting & 3.58 & .874 & 81 \\
\hline 82 & Past year resolutions of shareholders' meeting & 3.58 & .874 & 82 \\
\hline 83 & Top 10 stockholders in current year & 3.55 & .677 & 83 \\
\hline 84 & Employee shareholding information & 3.55 & .749 & 84 \\
\hline 85 & Listing of analysts following the firm & 3.55 & .749 & 85 \\
\hline 86 & $\begin{array}{l}\text { Option provided to register for future email alerts regarding press } \\
\text { releases, newsletters, etc. }\end{array}$ & 3.53 & 640 & 86 \\
\hline 87 & Charters of others committees & 3.53 & .751 & 87 \\
\hline 88 & Information of third party opinion about company & 3.50 & 679 & 88 \\
\hline 89 & Glossaries & 3.50 & .641 & 89 \\
\hline 90 & Past year resolutions of the Board of Directors & 3.50 & .847 & 90 \\
\hline 91 & $\begin{array}{l}\text { Information about managers, at least the identity and curriculum } \\
\text { vitae of executives }\end{array}$ & 3.43 & .712 & 91 \\
\hline 92 & Text of speeches and presentations & 3.40 & .709 & 92 \\
\hline 93 & Past year resolutions of the Supervisory Board & 3.40 & .810 & 93 \\
\hline 94 & Phone number to investor relations & 3.40 & 1.033 & 94 \\
\hline 95 & Postal address to investor relations & 3.32 & .917 & 95 \\
\hline 96 & Monthly or weekly sale or operating data & 3.25 & .840 & 96 \\
\hline 97 & E-mail to investor relations & 3.15 & .834 & 97 \\
\hline
\end{tabular}

(1 = not important at all; 5 = very important $)$

Meanwhile, Table 4 shows items important in presentation dimension based on the mean value. The findings show that 52 out of 58 items exceeded the mean value of 3.50 and this shows the importance of IFR similar to previous studies in content dimension (Ali Khan et al., 2012; Ali Khan, 2010; Ali Khan \& Ismail, 2010; Ali Khan \& Ismail, 2008; Ho \&Kar, 2001).Furthermore, 15 items were categorised as very important by exceeding 4.00 of the level of index presentation dimension. Meanwhile, six items were categorised as unimportant with a mean lesser than 3.50. The top five IFR disclosure items for presentation dimension are: (1) loading time of 
the website below 10 seconds, (2) annual report in PDF format, (3) hyperlinks inside the annual report, (4) ability to download reports, and (5) hyperlinks to financial analysts; while, the lowest five items in presentation dimension are: (1) use of frames, (2) video files,(3) chat room, (4) flashes, and (5) sound files. Previous studies indicated that the reasons an increasing number of users are dissatisfied in regards to financial reporting are that it is not updated in the current year which will put delay in publishing the financial report and it lacks access to adequate information (Mirshekary \& Saudagaran, 2005; Joshi \& Modhahki, 2003; Naser et al., 2003; Ho \& Kar, 2001). Therefore, using PDF, which is an Acrobat format, makes it easier for users to obtain information in IFR, consequently making it an attractive medium when accessing financial reports on the web browser, search engine, or hyperlinks (Lymer \& Debreceny, 2003; Ho $\&$ Kar, 2001). Another way IFR should be attractive for users is that the ability to search the content of the report by using keywords would improve the accessibility of the information download that results in more equitable information dissemination (Fisher et al., 2004; Oyelere et al., 2003; Fisher et al., 2000). In short, the findings on the presentation dimension are quite consistent with the previous researches in this field of study.

Table 4: Auditors' Perception on the Disclosure Item for Presentation Dimension

\begin{tabular}{|c|c|c|c|c|}
\hline \multicolumn{2}{|c|}{ Disclosure Item } & Mean & Std. Dev. & Rank \\
\hline \multicolumn{5}{|c|}{ Great importance } \\
\hline 1 & Loading time of the website below 10 seconds & 4.32 & .616 & 1 \\
\hline 2 & Annual report in PDF format & 4.32 & .616 & 2 \\
\hline 3 & Hyperlinks inside the annual report & 4.18 & .712 & 3 \\
\hline 4 & Ability to download reports & 4.12 & .607 & 4 \\
\hline 5 & Hyperlinks to financial analysts & 4.10 & .709 & 5 \\
\hline 6 & Link to table of contents & 4.08 & .474 & 6 \\
\hline 7 & Link to homepage & 4.08 & .572 & 7 \\
\hline 8 & $\begin{array}{l}\text { There are investment calculators available (e.g. investment return or } \\
\text { dividend calculator) }\end{array}$ & 4.07 & .730 & 8 \\
\hline 9 & Internal search engine & 4.05 & .552 & 9 \\
\hline 10 & Help information/site & 4.05 & .783 & 10 \\
\hline 11 & Users can download the full annual reports in sections & 4.05 & .846 & 11 \\
\hline 12 & $\begin{array}{l}\text { Financial information can be viewed in more than one currency (UKE } \\
\text { \& US\$) }\end{array}$ & 4.05 & .904 & 12 \\
\hline 13 & Table of content/sitemap & 4.02 & .620 & 13 \\
\hline 14 & Financial data in processable format (such as Excel) & 4.02 & .768 & 14 \\
\hline 15 & Use of presentation slides & 4.00 & .716 & 15 \\
\hline \multicolumn{5}{|c|}{ Moderate Important } \\
\hline 16 & Link to top homepage & 3.95 & .552 & 16 \\
\hline 17 & Annual report in HTML format & 3.93 & .797 & 17 \\
\hline 18 & Next/previous bottoms to navigate sequentially & 3.90 & .545 & 18 \\
\hline 19 & $\begin{array}{l}\text { Users can compare and analyse comparative stock or other } \\
\text { performance on the same screen }\end{array}$ & 3.90 & .841 & 19 \\
\hline 20 & Menu click over & 3.85 & .662 & 20 \\
\hline 21 & Menu pull-down & 3.85 & .662 & 21 \\
\hline 22 & One click to get to investors relations information & 3.85 & .700 & 22 \\
\hline 23 & Format of reports suitable for calculations & 3.85 & .802 & 23 \\
\hline 24 & Change to printing friendly format possible & 3.82 & .675 & 24 \\
\hline 25 & Hyperlinks texts & 3.82 & .712 & 25 \\
\hline 26 & Clear boundaries for annual reports & 3.80 & .648 & 26 \\
\hline 27 & Online feedback & 3.80 & .687 & 27 \\
\hline
\end{tabular}


28 Online shareholder services available (e.g. change address, dividend paid directly into account)

29 Annual report in multiple file format

30 Use of multimedia technology (in general)

$3.78 \quad .862$

31 Users can download the financial information in more than one type of format

$\begin{array}{lll}3.78 & .768 \quad 30\end{array}$

32 Hyperlinks to data on a third-party's website

$3.78 \quad .920$

33 Direct e-mail hyperlinks to investor relations

$\begin{array}{lll}3.75 & .707 \quad 32\end{array}$

34 Direct e-mail contacts (feedback) available

$3.75 \quad .707$

35 Content can be viewed in different browsers (Internet Explorer and Netscape)

3.72

.640

36 Download plug-in on spot

$3.72 \quad .679$

37 One click to get to press releases or news

$3.70 \quad .648$

38 External links to related content

$3.70 \quad .723$

39 Online investor information order service

$\begin{array}{lll}3.68 & .730 \quad 39\end{array}$

40 User can subscribe to public announcement via e-mail

3.68

.797

41 There is information concerning technical devices (formats, size of downloads)

42 Moving picture such as JAVA applications

3.68

.829

\section{Annual meeting}

46 Function to recommend the page

$\begin{array}{lll}3.60 & .609 & 46\end{array}$

47 Users have a choice of download (black and white or full colour)

49 Contact to the webmaster

$\begin{array}{lll}3.55 & .749 & 50 \\ 3.50 & .784 & 51\end{array}$

50 E-mail alerts

51 Service to change data in the Share register online

$\begin{array}{lll}3.50 \quad .816 & 52\end{array}$

52 Conferences

$\begin{array}{lll}3.37 \quad .838 & 53\end{array}$

53 Graphic images

$3.35 \quad .802$

54

55 Video files

$\begin{array}{lll}3.35 & .893 \quad 55\end{array}$

56 Chat room

$\begin{array}{lll}3.28 & .877 \quad 56\end{array}$

\begin{tabular}{ll}
57 & Flashes \\
58 & Sound files \\
\hline
\end{tabular}

(1 = not important at all; 5 = very important $)$

As a conclusion, based on the auditors' views and feedback, a number of 90 out of 97 items were identified as the basis for IFR index measurement for content dimension. On the other hand, 52 out of 58 items were identified as the basis for IFR index measurement for presentation dimension. The overall findings indicate that a total of 142 items out of 155 items were identified as the basic measurement to evaluate the level of IFR for Bursa Malaysia's listed companies. Therefore, the minimum total score of 3.50 is similar to previous studies (Ali Khan et al., 2012; Ali Khan, 2010; Ali Khan \& Ismail, 2010; Ali Khan \& Ismail, 2008; Ho \&Kar, 2001).

\section{Conclusion and Research Implication}

The aim of this study is to explore the perception of auditors in Malaysia on the important of items of content and presentation dimension in indices of IFR. The findings showed that the five most important items of disclosure for content dimension are income statement of current year, income statement of past years, cash 
flow statement of current year, notes to financial statement of current years and balance sheet of current year. Secondly, auditors ranked their perception on the importance of five most important items for presentation dimension as loading time of the website below ten seconds, annual report in PDF format, hyperlinks inside the annual report, ability to download reports and hyperlinks to financial analysts. As a conclusion, based on the auditors' views and feedback, a number of 90 out of 97 items were identified as the basis for IFR index measurement for content dimension. On the other hand, 52 out of 58 items were identified as the basis for IFR index measurement for presentation dimension. The overall findings indicated that a total of 142 items out of 155 items were identified as the basic measurement to evaluate the level of IFR for Bursa Malaysia listed companies (Ali Khan et al., 2012; Ali Khan, 2010; Ali Khan \& Ismail, 2010; Ali Khan \& Ismail, 2008; Ho \& Kar, 2001). Furthermore, three items important for audit issues as perceived by auditors are the conversion or transposition process involved in publishing information on the internet is susceptible to error, information on the internet is exposed to accessibility and modification by unauthorised users both external and internal to the reporting entity, and information on the internet has the potential to be very fluid.

This study is being conducted in order to evaluate the important of IFR in terms of content and presentation dimension presented in order to know the level of index disclosure of financial reporting in IFR. The result of the study is contributed to the understanding among users in order to obtain information regarding the important items on IFR and also as information to list items in Bursa Malaysia to identify the important items in IFR for user's information. Based on the literature review, there are limited efforts from the previous studies regarding analysing the need of item checklist for annual report such as the content and presentation dimensions present in this field of study. Within the limited knowledge of the researchers, some of the previous studies only highlighted the content of annual report but did not take into consideration the needs of users in financial reporting such as presentation dimension as in this study, which brings to the effectiveness of using IFR as an attraction for users to obtain information. Moreover, there are limited efforts to study in detail the contribution on auditor by which IFR can create unique opportunities, challenges and implications for the auditing profession, or in other words, not simplifying the needs of auditors and the ways to minimise the problems that occur. Thus, the result of this study is important because it seeks to contribute to the empirical evidence of the items needed in content and presentation dimensions, which are present in Bursa Malaysia. There are no actions from the professional body issuing a formal standard of IFR (Fisher et al., 2004). In other words, no standardisation is written to improve the quality of IFR to make it more attractive and useful towards users. Hence, the result gained from the study acts as a guideline for preparers of financial reports to take action for continuous improvement and to minimise past mistakes to be repeated such as security problems and high degree of data manipulation. On the other hand, as discusses before, the implementation of IFR has contributed to the benefit of users but there are some limitations that should be minimised. Therefore, this paper provides important insights on item disclosure of IFR from the perspective of auditors in financial reporting which were not specifically highlighted by previous studies.

From the result of this study, there are some limitations, where this study should have been conducted with more time and more respondents so that perhaps a different result may be achieved to measure higher potential on accuracy of data. In addition, the scope of the study is only focused in Johor Bahru, Johor due to the time constraint of this study. Most of the respondents came from the auditors group, which is part of the users of financial reporting. Hence, the result of this study might not produce comprehensive result as they were only for auditors and not the variety of user of financial reporting such as accountant, manager, academician, student, tax officer, bank officer, investor, potential investor, etc. There was also less participation in answering the set of questionnaires due to time constraints on respondents and less effort to fill up the questionnaire. Implementation has brought dissatisfaction towards the users of financial reporting. Furthermore, it may also affect the perception of auditors on IFR, which are the main users of financial reporting. There are several suggestions provided by the researcher, mainly based on the limitation of the study. I hope that further research can be carried out involving a larger sample size. Besides that, the research can also be expanded to other states in Malaysia to obtain more perception and feedback. In addition, by extending the duration of collecting the questionnaire, it enables respondents to spend more time to answer the set of questionnaire. There may also be other research procedures that can be used such as email or interview to obtain more feedback on IFR. Further research can be carried out not only focusing on the auditors, but other users of financial reporting as well as those who study in detail about the audit issues in IFR. To make it more interesting, future researchers can make comparison between preparers and users' 
perception on the IFR issues and for the evaluation of perception, they should address the varying opinion among these groups. In addition, future research can be carried out to investigate the contributions of IFR in creating unique opportunities, challenges and implications for the auditing profession. Lastly, it can obtain feedback from the professional bodies regarding auditing issues in IFR.

Acknowledgement: The financial support for the authors' research from Ministry of Higher Education (MOHE), Malaysia and Research Management Center (RMC), Universiti Teknologi Malaysia, Johor Bahru, Johor, Malaysia vote no. Q.130000.2629.07J40 by Research University Grant (RUG) also appreciated.

\section{References}

Abdul-Rahman, A. (2001). The Use and Perceived Importance of Annual Reports by Accountants in the Service Industry in Malaysia. Asian Review of Accounting, 9(2), 117-126.

Alattar, J. L. \& Al-Khater, K. (2007). An Empirical Investigation of Users' Views on Corporate Annual Report in Qatar. International Journal of Commerce and Management, 11(4), 312-325.

Al-Htaybat, K. (2011). Corporate Online Reporting in 2010: A Case Study in Jordan. Journal of Financing Reporting and Accounting, 9(1), 5-26.

Ali Khan, M. N. A. \& Ismail, N. A. (2009). Internet Financial Reporting in Malaysia, Factors, Pros and Cons. Accountants Today, 22(2), 28-31.

Ali-Khan, M. N. A. (2010). Pelaporan Kewangan Menerusi Internet Indeks: Tahap Pelaporandan Faktor Penentunya. Unpublished PhD Dissertation: Universiti Utara Malaysia, Sintok Kedah.

Ali-Khan, M. N. A. \& Ismail, N. A. (2011).The Level of Internet Financial Reporting of Malaysian Companies. Asian Journal of Accounting and Governance, 2, 27-39.

Ali-Khan, M. N. A. \& Ismail, N. A. (2012). Various Aspects of Internet Financial Reporting: Evidence from Malaysian Academician. Journal of Global Business and Economics, 4(1), 1-15.

Barlett, J. E., Kotrlik, J. W. \& Higgins, C. C. (2001). Organizational Research: Determining Appropriate Sample Size in Survey Research. Information Technology, Learning, and Performance Journal, 9(1), 43-50.

Celik, O., Ecer, A. \& Karabacak, H. (2006).Impact of Firm Specific Characteristics on the Web Based Business Reporting: Evidence from the Companies Listed in Turkey. Problems and Perspectives in Management, 4(3), 100-133.

Creswell, J. W. (2005). Educational Research: Planning, Conducting, and Evaluating Quantitative \& Qualitative Research. ( $2^{\text {nd }}$ Ed.). New Jersey: Pearson Prentice Hall.

Davies, M. B. (2007). Doing a Successful Research Project. New York: Palgave Macmillan.

Debreceny, R., Gray, G. L. \& Rahman, A. (2002).The Determinants of Internet Financial Reporting. Journal of Accounting and Public Policy, 21(4-5), 371-394.

Deller, D., Stubenrath, M. \& Weber, C. (1999). A Survey on the Use of the Internet for Investor Relations in the USA, the UK and Germany. The European Accounting Review, 8(2), 351-364.

Field, A. P. (2005). Discovering Statistics Using SPSS (2 ${ }^{\text {nd }}$ Ed.). London: Sage.

Fisher, R., Oyelere, P. \& Laswad, F. (2004). Corporate Reporting on the Internet: Audit Issues and Content Analysis of Practices. Managerial Auditing Journal, 19(3), 412-439.

Griffiths, P. (2012). Information Audit: Towards Common Standards and Methodology. Business Information Review, 29(1), 39-51.

Hansen, J. V. (2001). Internet Commerce Security: Issues and Model for Control Checking. Journal of the Operational Research Society, 52(10), 1159-1164.

Heller, T. \& Greene, S. (2012). Using SPSS for Data Analysis: Support Document for SPSS Output Tables. UWStout Office of Planning, Assessment, Research and Quality (PARQ), 2-51.

Ho, S. S. M. \& Kar, S. W. (2001). A study of Corporate Disclosure Practice and Effectiveness in Hong Kong. Journal of International Financial Management and Accounting, 12(1), 75-100.

Ismail, T. H. \& Sobhy, N. M. (2009). Determinants of Auditors' Perception of the Work Needed in the Audit of Internet- Based Financial Report in Egypt. Journal of Applied Accounting Research, 10(2), 132-150.

Joshi, P. L. \& Al-Modhahki, J. (2003). Financial Reporting on the Internet: Empirical Evidence from Bahrain and Kuwait. Asia- Pacific Journal of Accounting, 11(1), 88-101.

Krejcie, R. V. \& Morgan, D. W. (1970). Determining Sample Size for Research Activities. Educational and Psychological Measurement, 30, 607-610. 
Ku-Ismail, K. N. I. \& Chandler, R. (2005).Perceptions of Professional Investors in Malaysia on the Usefulness of Quarterly Financial Reports. Jurnal Pengurusan, 24, 105-124.

Lymer, A. \& Debreceny, R. (2003). The Auditor and Corporate Reporting on the Internet: Challenges \& Institutional Responses. International Journal of Auditing, 7, 103-120.

Marshall, C. \& Rossman, G. B. (1999). Designing Qualitative Research. London: Stage Publication.

Mirshekary, S. \& Saudagaran, S. M. (2005). Perceptions and characteristics of financial statement users in developing countries: Evidence from Iran. Journal of International Accounting, Auditing and Taxation, $14,33-54$.

Mohd-Isa, R. (2006). Graphical Information in Corporate Annual Report: A Survey of Users and Preparers Perception. Journal of Financial Reporting and Accounting, 4(1), 39-60.

Moradi, M., Salehi, M. \& Arianpoor, A. (2011).A Study of the Reasons for shortcomings in establishment of Internet Financial Reporting in Iran. African Journal of Business Management, 5(8), 3312-3321.

Naser, K., Nuseibeh, R. \& Al-Hussaini, A. (2003).Users' Perceptions of Various Aspects of Kuwaiti Corporate Reporting. Managerial Auditing Journal, 18(6-7), 599-617.

Ohman, P. \& Wallerstedt, E. (2012). Audit Regulation and the Development of the Auditing Profession: The Case of Sweden. Accounting History, 17(2), 241-257.

Oyelere, P. \& Kuruppu, N. (2012).Voluntary internet financial reporting practices of listed companies in United Arab Emirates. Journal of Applied Accounting Research, 13(3), 298-315.

Oyelere, P., Laswad, F. \& Fisher, R. (2003). Determinants of Internet Financial Reporting by New Zealand Companies. Journal of International Financial Management and Accounting, 14(1), 1-39.

Radhakrishna, R. B. (2007). Tips for Developing and Testing Questionnaire or Instrument. Journal of Extension, 45(1), 1-4.

Samaha, K., Dahawy, K. Abdel-Meguid, A. \& Abdallah, S. (2012). Propensity and comprehensiveness of corporate internet reporting in Egypt: Do board composition and ownership structure matter? International Journal of Accounting and Information Management, 20(2), 142-170.

Stoel, D., Havelka, D. \& Merhout, J. W. (2012). An Analysis of Attributes that Impact Information Technology Audit Quality: A Study of IT and Financial Audit Practitioners. International Journal of Accounting Information System, 13, 60-79.

Sumiani, Y., Haslinda, Y. \& Lehman, G. (2007). Environmental Reporting in a Developing Country: A Case on Status and Implementation in Malaysia. Journal of Cleaner Production, 15, 895-901.

Velmurugan, M. S. (2009). Security and Trust in E-Business: Problem and Prospects. International Journal of Electronic Business Management, 7(3), 151-158.

Virginia, M. C. \& Michael, J. C. (2003). Impact of SAS no.94 on computer audit techniques. Information System Control Journal, 1-9.

Xiao, J. Z., Jones, M. J. \& Lymer, A. (2002). Immediate Trends in Internet reporting. European Accounting Review, 11(2), 245-276. 